\title{
Challenge in diagnosis of COVID-19 in hemodialysis patient: a case report and brief review of the literature
}

\author{
Rizky Andhika ${ }^{1}$ - Afiatin Makmun ${ }^{1} \cdot$ Yovita Hartantri $^{2} \cdot$ Indra Wijaya $^{3} \cdot$ lan Huang ${ }^{4}$
}

Received: 14 September 2020 / Accepted: 26 December 2020 / Published online: 16 January 2021

(c) Japanese Society of Nephrology 2021

\begin{abstract}
Diagnosis of COVID-19 in end-stage kidney disease (ESKD) patients on hemodialysis is challenging, as the symptoms are often atypical. Herein, we reported a confimed case of COVID-19 in a patient on maintenance hemodialysis. A 38-year-old man with ESKD on regular hemodialysis initially presented with progressive shortness of breath and dry cough, without fever. He had lymphopenia, and chest X-ray suggested pulmonary edema with cardiomegaly and suspected bilateral bronchopneumonia. The patient clinically improved after 7 days of hospitalization, and was subsequently discharged from hospital. Ten days after being discharged, the patient was re-admitted with progressive shortness of breath and dry cough, without fever. SARS-CoV-2 infection was later confirmed by a qualitative RT-PCR test and the diagnosis COVID-19 pneumonia was established. We presented a case of atypical presentation of COVID-19 in an ESKD patient on maintenance hemodialysis with a brief review of the current literature.
\end{abstract}

Keywords COVID-19 $\cdot$ Hemodialysis $\cdot$ End-Stage Kidney Disease $\cdot$ Atypical presentation

\section{Introduction}

In December 2019, an infectious pneumonia caused by severe acute respiratory syndrome coronavirus 2 (SARSCoV-2) emerged in Wuhan, China. The disease then rapidly spread worldwide, and the World Health Organization (WHO) declared coronavirus disease 2019 (COVID-19) as a global public health emergency [1]. The spectrum of the disease ranges from asymptomatic to fatal multiorgan failure with features of hyperinflammation and hypercoagulable

Rizky Andhika

rizkyandhikaipd@gmail.com

Afiatin Makmun

afiatinmakmun@gmail.com

Yovita Hartantri

yhartantri@gmail.com

Indra Wijaya

indrawijayaipd@gmail.com

Ian Huang

ianhuang2108@gmail.com

1 Division of Nephrology and Hypertension, Department of Internal Medicine, Faculty of Medicine, Universitas Padjadjaran/Hasan Sadikin General Hospital, Bandung, Indonesia state [2-5]. Cardiac arrhythmias in COVID-19 are gaining attention as potential complications of SARS-CoV-2 because of its association with increased risk of poor outcome in COVID-19 [6, 7]. Clinical characteristics of patients associated with a high risk of severe disease and death include older age, underlying cardiac disease, chronic kidney disease, diabetes, and hypertension [8-13]. End-stage kidney disease (ESKD) patients on regular hemodialysis are considered to be at high risk for SARS-CoV-2 infection. This special population is vulnerable because they usually have

2 Division of Infectious Disease and Tropical Medicine, Department of Internal Medicine, Faculty of Medicine, Universitas Padjadjaran/Hasan Sadikin General Hospital, Bandung, Indonesia

3 Division of Hematology and Medical Oncology, Department of Internal Medicine, Faculty of Medicine, Universitas Padjadjaran/Hasan Sadikin General Hospital, Bandung, Indonesia

4 Department of Internal Medicine, Faculty of Medicine, Universitas Padjadjaran/Hasan Sadikin General Hospital, Bandung, Indonesia 
several comorbidities, suppressed immunity, and inevitable frequent visits to the dialysis unit. Information about symptoms, laboratory and radiologic abnormalities, and the use of rapid diagnostic tests for COVID-19 in patients on maintenance hemodialysis is limited. Herein, we report our first experience with a confirmed COVID-19 case in a patient with ESKD on regular hemodialysis.

\section{Case report}

A 38-year-old male ESKD patient on regular hemodialysis presented with shortness of breath and dry cough for 3 days. He had a history of fever 3 days prior admission. He denied any history of contact with a confirmed COVID-19 patient or travel to epidemic areas. He had been on hemodialysis three times weekly through an AV Fistula since 2016. He had a history of hypertension, but no diabetes or cardiovascular, cerebrovascular, or chronic obstructive pulmonary disease (COPD), nor chronic liver disease. His regular medications included Irbesartan, Amlodipine, calcium carbonate, and folic acid.

On the first admission, his physical examination revealed tachypnea, peripheral oxygen saturation of $90 \%$ within room air, no fever, with normal jugular venous pressure $(5+2 \mathrm{~cm}$ $\mathrm{H}_{2} \mathrm{O}$ ). Chest examination revealed bilateral crackles. He did not have peripheral edema. Laboratory tests showed anemia (hemoglobin level $8.8 \mathrm{~g} / \mathrm{dL}$ ), a white blood cell count of 5160 cells $/ \mu \mathrm{L}$, with a low absolute lymphocyte count of 570 cells $/ \mu \mathrm{L}$, and a thrombocyte count of 153,000 cells $/ \mu \mathrm{L}$ (Table 1). Chest X-ray showed bilateral peripheral opacities, suggesting pulmonary edema with cardiomegaly, and suspected bilateral bronchopneumonia (Fig. 1). After one hemodialysis session, the symptoms slightly improved but still with an increased work of breathing. The patient was diagnosed with community-acquired pneumonia and was
Table 1 Laboratory results according to the day of illness

\begin{tabular}{lllllll}
\hline Measure & Baseline & $\begin{array}{l}\text { Day 3 (1st } \\
\text { admission) }\end{array}$ & Day 7 & $\begin{array}{l}\text { Day 21 (2nd } \\
\text { admission) }\end{array}$ & Day 23 & Day 28 \\
\hline Hemoglobin (gr/dL) & 9.3 & 8.6 & 9.1 & 9.2 & 6.1 & 10.9 \\
White blood cell count $\left(10^{3} / \mathrm{uL}\right)$ & 7.20 & 5.16 & 6.15 & 19.56 & 16.81 & 9.15 \\
Neutrophil count (/uL) & 6.500 & 4.130 & 5.290 & 15.450 & 14.620 & 6.490 \\
Lymphocyte count (/uL) & 1.296 & 570 & 490 & 920 & 660 & 1.360 \\
Platelet count (103/uL) & 162 & 153 & 138 & 189 & 263 & 240 \\
Ureum (mg/dL) & 108 & 167 & 116.4 & 164 & 113 & 146 \\
Creatinine (mg/dL) & 7.24 & 12.6 & 9.26 & 9.34 & 9.23 & 8.46 \\
Procalcitonin (ng/mL) & & & & 4.29 & & \\
SARS-CoV-2 rapid IgG/IgM & & & Negative & Positive & & \\
$\quad$ combine antibody test & & & & Positive & & Negative $^{\mathrm{a}}$ \\
PCR SARS-CoV-2 & & & & &
\end{tabular}

$P C R$ polymerase chain reaction, $S A R S-C o V-2$ severe acute respiratory syndrome Coronavirus 2

${ }^{a}$ The test was negative for two times over a period of $24 \mathrm{~h}$
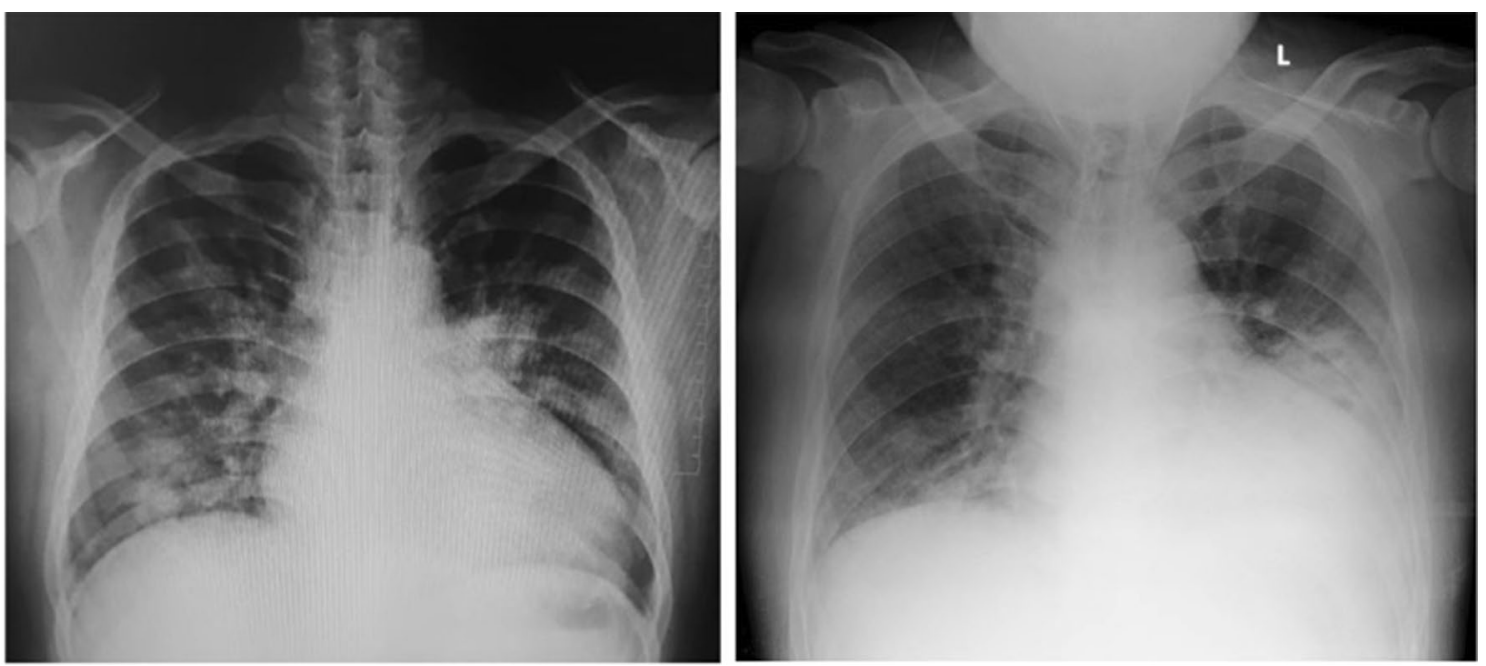

Fig. 1 Chest X-ray: day 3 of illness/first admission (left); day 21 of illness second admission (right) 
started on empirical antibiotics. COVID-19 was not suspected at first, as he denied any epidemiological exposure.

On the fifth day of hospitalization, even though the patient's respiratory condition began to improve, his blood tests still showed a very low absolute lymphocyte count (490 cells $/ \mu \mathrm{L}$ ) relative to his baseline values (Table 1 ), with a total white blood cell count of 6150 cells $/ \mu \mathrm{L}$. Suspicion of viral pneumonia was raised, and a SARS-CoV-2 antibody test was performed. The result was negative. Due to the early surge of COVID-19 pandemic in our hospital, the patient was "semi-isolated" in a single-patient room to minimize contact with other patients. The patient was discharged on the seventh day of hospitalization and advised to re-do the SARS-CoV-2 antibody test after 10-14 days.

Ten days after the patient was discharged from hospital, he presented with a progressive shortness of breath and dry cough, without fever. His physical examination revealed tachypnea, peripheral oxygen saturation was $88 \%$ in room air, and he was afebrile. Laboratory tests showed anemia (hemoglobin level $9.2 \mathrm{~g} / \mathrm{dL}$ ), a white blood cell count of 15,452 cells/ $\mu \mathrm{L}$, with a low absolute lymphocyte count of 920 cells $/ \mu \mathrm{L}$, and a platelet count of 153,000 cells $/ \mu \mathrm{L}$. His repeat chest X-rays demonstrated evolution of the bilateral multifocal opacities, consistent with the atypical pneumonia (Fig. 1). The patient was tested with the Rapid IgM/ IgG Combined Antibody test, with a positive result. SARSCoV-2 infection was later confirmed by the qualitative RTPCR test of nasopharyngeal and oropharyngeal specimens, and the diagnosis of COVID-19 pneumonia was established. Due to the high level of serum procalcitonin (Table 1), coinfection with bacterial pneumonia was suspected. He was treated with oxygen supplementation, supportive packed red cells transfusion, empirical intravenous antibiotics, prophylactic-dose of heparin, regular hemodialysis, and received a COVID-19 regimen according to the local standard of care for in early pandemics, consisting of Hydroxychloroquine, Azithromycin, and Oseltamivir for 5 days. The patient did not receive any erythropoietin stimulating agent during hospitalization due to concerns of increasing the risk of thromboembolic event. His clinical condition improved gradually, and after repeated negative qualitative RT-PCR tests, the patient was discharged from the hospital (Table 2).

\section{Discussion}

During the COVID-19 pandemic, ESKD patients on hemodialysis are considered to be at high risk for SARS-CoV-2 infection. They are likely to be immunocompromised with a high prevalence of multiple comorbidities [14, 15]. Regular compulsory visits to the dialysis facility, a place where peoples are crowding for certain amount of time, also increase the risk of being exposed to this communicable disease. The prevalence of COVID-19 and its severity among hemodialysis patients varies worldwide [16]. Xiong et al. reported 154 cases of COVID-19 among 7153 hemodialysis patients in China [17], while Goicoechea et al. reported 36 confirmed COVID-19 cases among 283 hemodialysis patients in Spain [18]. Moreover, Alberici et al. reported 94 patients positive for SARS-CoV-2 infection within an overall population of 643 hemodialysis patients in Italy [19].

Our center is the top referral hospital for COVID-19 in the West Java Region, and the case presented here was our very first confirmed case of COVID-19 in a hemodialysis patient at the beginning of pandemic (our patient was diagnosed as COVID-19 on 23 May 2020). Initially, we were quite startled with surprisingly rare case of COVID19 among relatively high prevalence of ESKD patients on chronic dialysis in West Java which accounts for a total of 33,828 patients in this specific region [20]. It seemed that researchers around the globe were also wondering this same question, "Why COVID-19 may be less severe in dialysis patients?" [21]. These controversial issues regarding the low prevalence and severity of COVID-19 among ESKD on dialysis aroused when an initial study reported a lesser severity of COVID-19 among those individuals [22]. The surge of new COVID-19 cases among hemodialysis patients in our region after this first case report, along with the result of

Table 2 Timeline

\begin{tabular}{ll}
\hline Day of illness & Events \\
\hline Day 1 & The onset of shortness of breath, cough, and fever \\
Day 3 & Persistent shortness of breath and cough. Patient was admitted to hospital \\
Day 7 & SARS-CoV-2 Rapid IgG/IgM combine antibody test: negative \\
Day 9 & Clinically improved. He was discharged from hospital, and advised to re-check the \\
& antibody in the next 10-14 days \\
Day 21 (23 May 2020) & Shortness of breath, cough after dialysis session. He was admitted again to the hospital \\
& SARS-CoV-2 Rapid IgG/IgM combine antibody test: positive \\
Day 28 & Later confirmed with PCR: Positive \\
\hline
\end{tabular}

$P C R$ polymerase chain reaction, $S A R S-C o V-2$ severe acute respiratory syndrome coronavirus 2 
our previous meta-analysis resolved the issues and revealed the high overall prevalence of COVID-19 among dialysis patients, and high rates of severe COVID-19 and mortality among hospitalized ESKD patients on dialysis (18.4\%, $45.3 \%$, and $26.8 \%$, respectively) [16].

The clinical manifestation of COVID-19 in hemodialysis patients can be atypical from the general population. The main symptoms of COVID-19 pneumonia in the general population include fever, cough, and dyspnea [9]. In our case, the patient presented with dyspnea and cough. $\mathrm{Wu}$ et al. found that fever is reported in 47\% of COVID-19 patients on hemodialysis, versus $90 \%$ in the control group (with normal kidney function) [23]. Reports showed that typical symptoms of COVID-19 pneumonia such as fever, cough, and dyspnea are less likely to be found in the hemodialysis population $[17,19,24]$. The wide spectrum of symptoms in the hemodialysis population makes it difficult to screen patients with SARS-CoV-2 infection. Symptoms can mimic uremia conditions or fluid overload from inadequate dialysis. We have summarized evidence from the current literature regarding the clinical manifestation of COVID-19 in ESKD patients on hemodialysis in Table 3.

The patient presented here had lymphopenia, a prominent laboratory finding of SARS-CoV-2 infection in the general population [25]. Low lymphocyte counts are common in chronic dialysis patients. Yoon et al. found an increased susceptibility of apoptosis of naive $T$ cell lymphocytes and memory T cells in patients with ESKD [26]. Ma et al. showed that $\mathrm{T}$ cell, Th cell, killer T cell, and NK cell counts are reduced in dialysis patients, irrespective of SARS-CoV-2 infection [27]. Therefore, lymphopenia with an absolute cutoff value may not be helpful to identify individuals with SARS-CoV-2 infection in hemodialysis patients. Nevertheless, lymphopenia that is lower than the previous baseline values might still provide an insight of underlying COVID19 , as we consistently found that lymphopenia is observed in hemodialysis patients with COVID-19 from many reports [17-19, 24, 28].

SARS-CoV-2 qualitative RT-PCR should be performed when there is a suspicion of viral pneumonia, but due to logistic limitations we used the SARS-CoV-2 Rapid IgG/ IgM Combined Antibody Test as the initial screening. Initially, a couple of weeks after the WHO announced the pandemic status, there were still limitations in COVID19 testing. Nasopharyngeal and oropharyngeal specimens had to be sent to the central laboratory in Jakarta $(115 \mathrm{~km}$ away from Bandung), and the results were available after 5-7 days. In our case, the SARS-CoV-2 Antibody Test was first negative (on the seventh day after onset of symptoms) and later positive (on the 21st day). We considered the possibility that the patient might have been infected by SARS-CoV-2 already on the first admission, but the antibody response was delayed.

In the general population, the IgM SARS-CoV-2 antibody can be detected 3-6 days after infection, while IgG can be detected after 8 days. Sun et al. found out that in up to $75 \%$ patients, IgM/IgG could be possibly detected in the first week [29]. Ying et al. showed that sensitivity, specificity, and accuracy of the Rapid IgG/IgM Combined Antibody Test for SARS-CoV-2 were different between three groups according to the interval between symptom onset and sample collection: "0-7 days," "8-15 days," and "> 16 days." Sensitivity was $18.7 \%, 100 \%$, and $100 \%$; specificity was $77.8 \%, 50 \%$, and $64.3 \%$; and accuracy was $40 \%, 87.5 \%$, and $93.9 \%$, respectively [30]. A majority of patients develop an antibody response in the second week after onset of symptoms. However, analysis of the dynamics of SARS-CoV-2 antibody is still ongoing in the general population, and even less is known about these dynamics in hemodialysis patients.

The kinetics of the antibody response to SARS-CoV-2 infection in hemodialysis patients remain to be determined. De Vriese et al. reported the first evaluation of potential antibody responses in six hemodialysis patients. They found that the IgG response against SARS-CoV-2 nucleocapsid $(N)$ protein occurred in the second week after symptom onset [31]. It remains to be confirmed whether those results are applicable to the entire hemodialysis population [32]. With the limited data available, the use of antibody-detecting rapid diagnostic tests is not recommended. It could be used in limited resource facilities with precaution at 10-14 days after onset of symptoms. However, further investigation to characterize the antibody response to SARS-CoV-2 infection in hemodialysis patients is encouraged to improve disease surveillance and epidemiologic research.

In summary, despite our several limitations in regard to the absence of several radiological and laboratory investigations (e.g., Pulmonary CT Scan, echocardiography, C-reative protein, and D-dimer), we have reported our very first case of ESKD on hemodialysis patient with COVID19 in our region. Atypical presentations of COVID-19 on this specific population are relatively frequent according to the current literature. More vigilant suspicion, early screening, and additional preventive precautions cannot be over-emphasized in dealing with COVID-19 among ESKD patients on hemodialysis. 
Table 3 Clinical characteristic of COVID-19 in hemodialysis patients

\begin{tabular}{|c|c|c|c|c|c|c|c|c|}
\hline Author & Place & Case $(n)$ & Male $(\%)$ & $\begin{array}{l}\text { Age } \\
\text { (mean/ } \\
\text { median) }\end{array}$ & Comorbidities & $\begin{array}{l}\text { Clinical manifes- } \\
\text { tation }\end{array}$ & $\begin{array}{l}\text { Laboratory find- } \\
\text { ings }\end{array}$ & $\begin{array}{l}\text { Radiologic find- } \\
\text { ings }\end{array}$ \\
\hline Xiong [17] & Wuhan, China & 131 & 57.3 & 63.3 & $\begin{array}{l}\text { Cardiovascular } \\
\text { disease } 68.7 \% \\
\text { Diabetes } 22.9 \% \\
\text { Hepatitis B } 8.4 \% \\
\text { Hepatitis C } 2.3 \% \\
\text { COPD 3.8\% } \\
\text { Cancer 1.5\% }\end{array}$ & $\begin{array}{l}\text { Fever } 51.9 \% \\
\text { Cough } 37.4 \% \\
\text { Dyspnea } 26 \% \\
\text { Fatigue } 45 \% \\
\text { Sputum produc- } \\
\text { tion } 29 \% \\
\text { Nausea/vomiting } \\
18 \% \\
\text { Diarrhea } 13 \% \\
\text { Sore throat } 7.7 \%\end{array}$ & $\begin{array}{l}\mathrm{Hb} 10.5 \\
(9.1-11.8) \\
\text { WBC 5.0 } \\
(3.8-7.3) \\
\text { Lymphocyte } 0.7 \\
\quad(0.5-1.1) \\
\text { Neutrophils } 3.9 \\
(3.0-6.1) \\
\text { PLT 144.2 } \\
(107-186)\end{array}$ & $\begin{array}{l}\text { CT scan image: } \\
\text { Ground-glass } \\
82.1 \% \\
\text { Cord Shadow } \\
7.7 \% \\
\text { Consolidation } \\
4.3 \% \\
\text { Lesion region: } \\
\text { Bilateral } 86.7 \% \\
\text { Left lung } 6.2 \% \\
\text { Right lung } 7.1 \%\end{array}$ \\
\hline Alberici [19] & Brescia, Italy & 94 & 65.9 & 72 & $\begin{array}{l}\text { Hypertension } \\
93 \% \\
\text { Diabetes } 43 \% \\
\text { Vascular Disease } \\
23 \% \\
\text { Cardiac Failure } \\
18 \% \\
\text { Ischemic Cardiac } \\
\text { disease } 17 \% \\
\text { Cancer } 12 \% \\
\text { COPD } 11 \%\end{array}$ & $\begin{array}{l}\text { Fever } 68 \% \\
\text { Cough 23\% } \\
\text { Dyspnea 25\% } \\
\text { Gastrointestinal } \\
6 \% \\
\text { Pharyngitis 2\% } \\
\text { Myalgia 17\% }\end{array}$ & $\begin{array}{l}\text { WBC 5.0 } \\
(3.9-6.4) \\
\text { Lymphocyte } 0.7 \\
(0.5-1.0) \\
\text { Neutrophils } 3.5 \\
(2.6-4.7) \\
\text { PLT 162 } \\
(126-229)\end{array}$ & $\begin{array}{l}\text { Chest X-ray: } \\
\text { No infiltrates 30\% } \\
\text { Unilateral infil- } \\
\text { trates } 25 \% \\
\text { Bilateral infiltrates } \\
45 \%\end{array}$ \\
\hline Valeri [24] & New York, US & $59 *$ & 56 & 63 & $\begin{array}{l}\text { Hypertension } \\
98 \% \\
\text { Diabetes } 69 \% \\
\text { Coronary artery } \\
\text { disease } 46 \% \\
\text { Cardiac failure } \\
18 \% \\
\text { Pulmonary } \\
\text { disease } 17 \%\end{array}$ & $\begin{array}{l}\text { Fever } 49 \% \\
\text { Cough 39\% } \\
\text { Dyspnea 36\% } \\
\text { Fatigue 22\% } \\
\text { Gastrointestinal } \\
\quad 15 \% \\
\text { Myalgia 8\% } \\
\text { Altered menta- } \\
\text { tion 5\% }\end{array}$ & $\begin{array}{l}\mathrm{Hb} 10.6 \\
(9.7-11.8) \\
\text { WBC } 6.0 \\
(4.5-7.8) \\
\text { Lymphocyte } 0.8 \\
(0.5-1.2)\end{array}$ & $\begin{array}{l}\text { Chest X-ray: } \\
\text { Bilateral opacities } \\
59 \% \\
\text { Unilateral opacity } \\
10 \% \\
\text { Pleural effusion } \\
7 \% \\
\text { Pulmonary Edema } \\
5 \% \\
\text { No acute findings } \\
19 \%\end{array}$ \\
\hline $\mathrm{Wu}[23]$ & Wuhan, China & 49 & 63 & 62 & $\begin{array}{l}\text { Hypertension } \\
92 \% \\
\text { Diabetes 20\% } \\
\text { Cardiovascular } \\
\text { disease 20\%; } \\
\text { Cerebrovascular } \\
\text { disease 2\% } \\
\text { Cancer 8\% } \\
\text { COPD 2\% } \\
\text { Chronic liver } \\
\text { disease 6\% }\end{array}$ & $\begin{array}{l}\text { Fever } 47 \% \\
\text { Cough } 49 \% \\
\text { Dyspnea } 45 \% \\
\text { Sputum Produc- } \\
\quad \text { tion 33\% } \\
\text { Fatigue 59\% } \\
\text { Anorexia 57\% } \\
\text { Diarrhea 12\% } \\
\text { Dizziness 14\% } \\
\text { Nausea } 8 \% \\
\text { Vomiting } 4 \% \\
\text { Sore throat } 7.7 \%\end{array}$ & $\begin{array}{l}\mathrm{Hb} 10.4 \\
(8.2-12.2) \\
\text { WBC } 5.6 \\
(4.7-7.6) \\
\text { Lymphocyte } 0.8 \\
\quad(0.5-1.0) \\
\text { Neutrophils } 4.0 \\
(3.1-5.6) \\
\text { PLT 169 } \\
(120-234)\end{array}$ & $\begin{array}{l}\text { CT scan: } \\
\text { Bilateral opacities } \\
82 \% \\
\text { Unilateral opacity } \\
10 \% \\
\text { No abnormality } \\
8 \%\end{array}$ \\
\hline Goicoechea [18] & Madrid, Spain & 36 & 64 & 71 & $\begin{array}{l}\text { Hypertension } \\
97 \% \\
\text { Diabetes } 64 \% \\
\text { Coronary heart } \\
\text { disease } 22 \% \\
\text { Dyslipidemia } \\
67 \% \\
\text { COPD 19\% }\end{array}$ & $\begin{array}{l}\text { Fever } 67 \% \\
\text { Cough } 44 \% \\
\text { Fatigue 25\% } \\
\text { Gastrointestinal } \\
\quad 17 \%\end{array}$ & $\begin{array}{l}\text { Hb } 10.6 \\
\quad(9.2-12.0) \\
\text { Lymphocyte } \\
0.79(0.32- \\
1.26) \\
\text { PLT } 164 \\
(98-230)\end{array}$ & $\begin{array}{l}\text { Chest X-ray: } \\
\text { Bilateral periph- } \\
\text { eral ground-glass } \\
\text { opacity } 61 \% \\
\text { Unilateral opacity } \\
19 \% \\
\text { Normal X-ray } 19 \%\end{array}$ \\
\hline
\end{tabular}

$H b$ hemoglobin $(\mathrm{g} / \mathrm{L}), W B C$ white blood cells $\left(10^{9} / \mathrm{L}\right)$; Lymphocyte $\left(10^{9} / \mathrm{L}\right)$; Neutrophils $\left(10^{9} / \mathrm{L}\right)$; PLT platelet $\left(10^{9} / \mathrm{L}\right)$

*2 patients on $\mathrm{PD}, 57$ patients on $\mathrm{HD}$ 
Funding The authors received no financial support for the authorship and/or publication of this article.

Data availability statement All the relevant data are available and included in the manuscript.

\section{Compliance with ethical standards}

Conflict of interest The authors declare that there is no conflict of interest.

Patient consent confirmation statement Patient consent was obtained to publish the findings of this case report.

\section{References}

1. Zhu N, Zhang D, Wang W, Li X, Yang B, Song J, Zhao X, Huang B, Shi W, Lu R, Niu P, Zhan F, Ma X, Wang D, Xu W, Wu G, Gao GF, Tan W. A novel coronavirus from patients with pneumonia in China, 2019. N Engl J Med. 2020;382(8):727-33.

2. Lim MA, Pranata R, Huang I, Yonas E, Soeroto AY, Supriyadi R. Multiorgan failure with emphasis on acute kidney injury and severity of COVID-19: systematic review and meta-analysis. Can J Kidney Heal Dis. 2020;7:1-12.

3. Wijaya I, Andhika R, Huang I. The use of therapeuticdose anticoagulation and its effect on mortality in patients with COVID-19: a systematic review. Clin Appl Thromb. 2020;26:1076029620960797.

4. Huang I, Pranata R, Lim MA, Oehadian A, Alisjahbana B. $\mathrm{C}$-reactive protein, procalcitonin, D-dimer, and ferritin in severe coronavirus disease-2019: a meta-analysis. Ther Adv Respir Dis. 2020;14:1-14.

5. Wijaya I, Andhika R, Huang I. Hypercoagulable state in COVID19 with diabetes mellitus and obesity: is therapeutic-dose or higher-dose anticoagulant thromboprophylaxis necessary? Diabetes Metab Syndr Clin Res Rev [Internet]. 2020;14(5):1241-2. Available from: https://linkinghub.elsevier.com/retrieve/pii/S1871 402120302630.

6. Pranata R, Huang I, Raharjo SB. Incidence and impact of cardiac arrhythmias in coronavirus disease 2019 (COVID-19): a systematic review and meta-analysis. Indian Pacing Electrophysiol J [Internet]. 2020;20(5):193-8. Available from: https://linkinghub .elsevier.com/retrieve/pii/S0972629220300875.

7. Yasmin Kusumawardhani N, Huang I, Martanto E, Sihite TA, Nugraha ES, Prodjosoewojo S, Hamijoyo L, Hartantri Y. Lethal arrhythmia (Torsade de Pointes ) in COVID-19: an event synergistically induced by viral associated cardiac injury, hyperinflammatory response, and treatment drug? Clin Med Insights Case Reports [Internet]. 2020;13:117954762097239. Available from: http://journals.sagepub.com/doi/https://doi.org/10.1177/11795 47620972397.

8. Huang C, Wang Y, Li X, Ren L, Zhao J, Hu Y, Zhang L, Fan G, Xu J, Gu X, Cheng Z, Yu T, Xia J, Wei Y, Wu W, Xie X, Yin W, Li H, Liu M, Xiao Y, Gao H, Guo L, Xie J, Wang G, Jiang R, Gao Z, Jin Q, Wang J, Cao B. Clinical features of patients infected with 2019 novel coronavirus in Wuhan, China. Lancet. 2020;395(10223):497-506.

9. Wang D, Hu B, Hu C, Zhu F, Liu X, Zhang J, Wang B, Xiang $\mathrm{H}$, Cheng Z, Xiong Y, Zhao Y, Li Y, Wang X, Peng Z. Clinical characteristics of 138 hospitalized patients with 2019 novel coronavirus-infected pneumonia in Wuhan, China. JAMA J Am Med Assoc. 2020;323(11):1061-9.
10. Huang I, Lim MA, Pranata R. Diabetes mellitus is associated with increased mortality and severity of disease in COVID-19 pneumonia — a systematic review, meta-analysis, and meta-regression: Diabetes and COVID-19. Diabetes Metab Syndr Clin Res Rev. 2020;14(4):395-403.

11. Pranata R, Lim MA, Huang I, Raharjo SB, Lukito AA. Hypertension is associated with increased mortality and severity of disease in COVID-19 pneumonia: a systematic review, metaanalysis and meta-regression. J Renin-Angiotensin-Aldosterone Syst. 2020;21(2):147032032092689.

12. Yonas E, Alwi I, Pranata R, Huang I, Lim MA, Gutierrez EJ, Yamin M, Siswanto BB, Virani SS. Effect of heart failure on the outcome of COVID-19-a meta analysis and systematic review. Am J Emerg Med. 2020;S0735-6757(20):30602-30602.

13. Pranata R, Supriyadi R, Huang I, Permana H, Lim MA, Yonas E, Soetedjo NNM, Lukito AA. The association between chronic kidney disease and new onset renal replacement therapy on the outcome of COVID-19 patients: a meta-analysis. Clin Med Insights Circ Respir Pulm Med. 2020;14:1179548420959165.

14. Pranata R, Huang I, Lim MA, Wahjoepramono PEJ, July J. Impact of cerebrovascular and cardiovascular diseases on mortality and severity of COVID-19-systematic review, meta-analysis, and meta-regression. J Stroke Cerebrovasc Dis. 2020;29(8):104949. https://doi.org/10.1016/j.jstrokecerebrov asdis.2020.104949.

15. Pranata R, Soeroto AY, Ian H, Lim MA, Santoso P, Permana H, Lukito AA. Effect of chronic obstructive pulmonary disease and smoking on the outcome of COVID-19. Int J Tuberc Lung Dis. 2020;24(8):838-843.

16. Andhika R, Huang I, Wijaya I. The severity of COVID-19 in endstage kidney disease patients on chronic dialysis. Ther Apher Dial. 2020;50(6):1744-9987.13597. Available from: https://onlinelibrary.wiley.com/doi/https://doi.org/10.1111/1744-9987.13597.

17. Xiong F, Tang H, Liu L, Tu C, Tian JB, Lei CT, Liu J, Dong JW, Chen WL, Wang XH, Luo D, Shi M, Miao XP, Zhang C. Clinical characteristics of and medical interventions for COVID-19 in hemodialysis patients in Wuhan. China. J Am Soc Nephrol. 2020;31(7):1387-97.

18. Goicoechea M, Sánchez Cámara LA, Macías N, Muñoz de Morales A, Rojas ÁG, Bascuñana A, Arroyo D, Vega A, Abad S, Verde E, García Prieto AM, Verdalles Ú, Barbieri D, Delgado AF, Carbayo J, Mijaylova A, Acosta A, Melero R, Tejedor A, Benitez PR, Pérez de José A, Rodriguez Ferrero ML, Anaya F, Rengel M, Barraca D, Luño J, Aragoncillo I. COVID-19: clinical course and outcomes of 36 hemodialysis patients in Spain. Kidney Int. 2020;98(1):27-34.

19. Alberici F, Delbarba E, Manenti C, Econimo L, Valerio F, Pola A, Maffei C, Possenti S, Lucca B, Cortinovis R, Terlizzi V, Zappa M, Saccà C, Pezzini E, Calcaterra E, Piarulli P, Guerini A, Boni F, Gallico A, Mucchetti A, Affatato S, Bove S, Bracchi M, Costantino EM, Zubani R, Camerini C, Gaggia P, Movilli E, Bossini N, Gaggiotti M, Scolari F. A report from the Brescia Renal COVID Task Force on the clinical characteristics and short-term outcome of hemodialysis patients with SARS-CoV-2 infection. Kidney International. 2020;98(1):20-6.

20. Indonesian Society of Nephrology. 11th Report of Indonesian Renal Registry 2018 [Internet]. Indonesian Renal Registry. 2018. Available from: https://www.indonesianrenalregistry.org/data/ IRR2018.pdf.

21. Pisani A, Rizzo M, Angelucci V, Riccio E. Covid-19 experience in hemodialysis patients: a cue for therapeutic heparin-based strategies? Nephron. 2020;144(8):383-5.

22. Ma Y, Ph D, Diao B, Ph D, Lv X, Liang W, Ph D, Zhu J, Ph D, Liu L, Ph D, Zhang S, Shen B, Ph D, Wang H, Ph D. COVID-19 in hemodialysis (HD) patients: report from one HD center in Wuhan, 
China. medRxiv. 2020. https://doi.org/10.1101/2020.02.24.20027 201.

23. Wu J, Li J, Zhu G, Zhang Y, Bi Z, Yu Y, Huang B, Fu S, Tan Y, Sun J, Li X. Clinical features of maintenance hemodialysis patients with 2019 novel coronavirus-infected pneumonia in Wuhan. China. Clin J Am Soc Nephrol. 2020;15(8):1139-45.

24. Valeri AM, Robbins-Juarez SY, Stevens JS, Ahn W, Rao MK, Radhakrishnan J, Gharavi AG, Mohan S, Ali HS. Presentation and outcomes of patients with ESKD and COVID-19. J Am Soc Nephrol. 2020;31(7):1409-15.

25. Huang I, Pranata R. Lymphopenia in severe coronavirus disease-2019 (COVID-19): systematic review and meta-analysis. J Intensive Care. 2020;8(1):36. Available from: https://www.jintensivecare.biomedcentral.com/articles/https://doi.org/10.1186/ s40560-020-00453-4.

26. Yoon JW, Gollapudi S, Pahl MV, Vaziri ND. Naïve and central memory $\mathrm{T}$ cell lymphopenia in end-stage renal disease. Kidney Int. 2006;70(2):371-6.

27. Ma Y, Diao B, Lv X, Zhu J, Liang W, Liu L, Bu W, Cheng H, Zhang S, Yang L, Shi M, Ding G, Shen B, Wang H. novel coronavirus disease in hemodialysis (HD) patients: Report from one HD center in Wuhan. China. medRxiv. 2020: https://doi. org/10.1101/2020.02.24.20027201.

28. Kuroki Y, Hiyama K, Minami J, Takeuchi M, Shojima M, Matsueda S, Nagae H, Nakano T. The first case of COVID-19 pneumonia in a hemodialysis patient in Japan. CEN Case Rep. 2020;9(4):404-8. https://doi.org/10.1007/s13730-020-00495-5.

29. Sun B, Feng Y, Mo X, Zheng P, Wang Q, Li P, Peng P, Liu X, Chen Z, Huang H, Zhang F, Luo W, Niu X, Hu P, Wang L, Peng H, Huang Z, Feng L, Li F, Zhang F, Li F, Zhong N, Chen L. Kinetics of SARS-CoV-2 specific IgM and IgG responses in COVID-19 patients. Emerg Microbes Infect. 2020;9(1):940-8.

30. Liu Y, Liu Y, Diao B, Ren F, Wang Y, Ding J, Huang Q. Diagnostic indexes of a rapid $\mathrm{IgG} / \mathrm{IgM}$ combined antibody test for SARS-CoV-2. medRxiv. 2020; https://doi. org/10.1101/2020.03.26.20044883.

31. De Vriese AS, Reynders M. IgG antibody response to SARSCoV-2 infection and viral RNA persistence in patients on maintenance hemodialysis. Am J Kidney Dis. 2020;76(3):440-1.

32. Dudreuilh C, Moutzouris D-A. Is SARS-CoV-2 serology relevant for hemodialysis patients with COVID-19? Am J Kidney Dis. 2020;S0272-6386(20)30784-8.

Publisher's Note Springer Nature remains neutral with regard to jurisdictional claims in published maps and institutional affiliations. 